$5 B 483$

82213

1869 
Hollinger Corp. pH 8.5 


\section{LAWS AND ORDINANCES}

RELATING TO THE

\section{PUBLIC PARKS}

OF THE

CITY OF BALTIMORE,

WITH THE

RULES AND REGULATIONS FOR THEIR GOVERNMENT.

B A L T I M O R E :

IIEAM PRESS OF WILLIAM K. BOYLE, Corner of Baltimore and St. Paul Streets.

1869 . 


$$
\begin{array}{r}
58 \times 83 \\
B 213 \\
1869
\end{array}
$$

Butrexper

JUN 301908

${ }^{\circ} \because \vdots \vdots$ 


\section{LAWS AND ORDINANCES}

RELATING TO THE

\section{PUBLIC PA RKS of $\mathrm{PIn}$}

\section{CITY OF BALTIMORE.}

\section{No. 124.}

RESOLUTION inquiring into the expediency of opening, widening, and improving the Avenues on the Eastern and Northern Boundaries of the City, and providing a like Avenue on the Western Boundary of the City.

Resolved, by the Mayor and City Council of Baltimore, That it is expedient to cause inquiry to be made into the propriety of opening, widening and improving the avenues on the Eastern and Northern boundaries of the city, as laid down on Poppleton's Map, and providing a like avenue on the Western boundary of the city.

Resolved, That John H. B. Latrobe, James Carroll, Fielding Lucas, Jr., the Mayor of the city, and the Presidents of the First and Second Branches of the City Council, be and they are hereby appointed Commissioners to inquire into and report upon the most feasible plan for opening, widening, extending and improving said ave- 
nues, and the expenses of the same, to the City Council at its next annual session; and that, with a view to enable them to act with more efficiency in this behalf, they be and are hereby empowered to employ a suitable surveyor, and call upon the City Commissioner for any assistance said officer may be able to afford them.

Resolved, That for the purpose of defraying the expenses of such surveys as the said Commissioners may deem proper to order, in connection with the improvement of a continuous avenue around the city, the sum of five hundred dollars, or so much thereof as may be necessary, shall be and the same is hereby appropriated out of any money in the treasury not otherwise appropriated.

Approved June 12, 1851.

Jno. H. T. ЈеRомe, Mayor.

Under the foregoing ordinance the Commissioners reported the line surveyed by Thomas P. Chiffelle, and shown by the green trace on Simmons' map of the city, of November, 1851.

No. 138.

RESOLUTION of Instruction to the Joint Committee for opening, widening and extending the Northern, Eastern and Western Avenues.

Resolved, by the Mayor and City Council of Baltimore, That the Commissioners heretofore appointed to inquire into and report upon the propriety of opening, widening and improving the avenues on the Eastern and Northern boundaries of the city, as laid down on Poppleton's plat, and providing a like avenue on the Western boundary, be 
and they are hereby authorized to embrace in their inquiry and report any changes they may deem advisable in the location of the avenues aforesaid, and generally all such matters as they may think calculated to place the whole subject before the City Council at its next annual session.

Approved June 21, 1851.

JNo. H. T. Jeroye, Mayor.

\section{No. 114.}

RESOLUTIONS in regard to the further prosecution of the enquiry relating to Boundary Avenue.

Resolved, by the Mayor and City Council of Baltimore, That the Commissioners heretofore appointed under Resolutions No. 124 and No. 138, approved respectively on the 12th and 21st of June, 1851, be, and they are hereby continued, with instructions to complete the enquiry under their charge, by causing such additional surveys to be made as shall enable them to ascertain and mark upon the ground the best location, under all circumstances, and in view of the actual construction of the avenues referred to in the said resolutions, as well as of an avenue connecting the southern extremity of the Western avenue with Fort avenue.

Resolved, That the said Commissioners be required to include in their report detailed estimates of the cost of the plan adopted by them, including, as far as the same can be ascertained, the probable cost of the ground required for the work, enumerating the respective proprietors thereof.

Resolved, That for the purpose of defraying the expenses of the work thus required to be done, the sum of five thousand dollars, or so much thereof as may be necessary, shall 
be, and the same is hereby appropriated, out of any money in the treasury not otherwise appropriated.

Approved May 28, 1852.

JNO. H. T. Jerome, Mayor.

Under this ordinance the Commissioners reported the line surveyed by August Faul, and recommended it to the Councils. It is shown on Simmons' map of 1853 by a blue trace.

\section{No. 44 .}

Extract from An ORdinance empowering $W m$. H. Travers, Wm. S. Browning, Wm. De Goey, Rob't Cathcart, Joshua B. Sumwalt, and those who are now or may hereafter become associated with them and their assigns, to build and lay down tracks for a Passenger Rail Road on Baltimore Street and other streets.

SEction 14. And be it further enacted and ordained, That the said association shall, by their Treasurer, under oath, pay into the hands of the City Register, quarterly, one-fifth of the gross receipts accruing from the passenger travel upon said roads located within the city limits under this ordinance, or any extension of said limits which may be determined upon hereafter, the same to be applied to the establishment and improvement of the city boundary avenue as reported upon at the annual session of the Mayor and City Council of Baltimore in 1853, by commissioners appointed at the annual session of 1851 , and to the locttion, purchase and improvement of such Park or Parks as may be determined upon hereafter by the Mayor and City Council of Baltimore, for the benefit of the people of said city; said park or parks not to comprise an area of less than fifty acres each; and the said Mayor and City Council shall have the power, on the completion of said im- 
provements, to reduce the rate of fare on passenger travel to such limit within the range of one-fifth of the gross receipts of said road as they may deem expedient and advisable, the city at the same time relinquishing her interest in the receipts from said road to the extent of said reduction on said fare.

Approved March 28, 1859.

Tho: Swann, Mayor.

\section{No. 227.}

Resolution appointing a Commission in relation to the proposed Public Parks.

Whereas, as one-fifth of the revenue from the Passenger Railway Company is to be devoted to the purchase of a Park or Parks for the City of Baltimore; and whereas, a considerable portion of the funds are already in the hands of the Register, and more accruing every day ; and whereas, it is fitting that some action looking to a proper selection of the Park or Parks, and the purchase of the same should be taken by the present Council ; therefore,

Resolved, by the Mayor and City Council of Baltimore, That the Mayor be, and he is hereby authorized and empowered to appoint four discreet persons, who with the Mayor shall constitute a commission, to select and purchase in the name of the Mayor and City Council, a site or sites, the number of acres, \&c., for the proposed Park or Parks, and that said commission shall serve without pay or emolument.

Approved June 4, 1860.

Tho: Swann, Mayor.

Under this resolution, the Mayor appointed John H. B. Latrobe, William E. Hooper, Robert Leslie and Columbus O'Donnell. 


\section{No. 60.}

An Ordinance to provide for a Public Park or Parks.

Secrion 1. Be it enacted and ordained by the Mayor and City Council of Baltimore, That whenever the Commissioners appointed under a resolution of the Mayor and City Council of Baltimore, entitled "Resolution appointing a commission in relation to the proposed Public Parks," shall certify to the Register, under their respective hands, that they have purchased the site or sites for a Park or Parks, describing the same in their said certificate, and stating the price agreed to be paid therefor, and the terms of sale, it shall be the duty of the said Register to issue and deliver to the said commission, certificates of stock of the Mayor and City Council of Baltimore, in the usual form, redeemable at the end of thirty years from the date thereof, and designated on the face of the certificate as "Public Park Stock," for the amount of said purchase money, and in accordance with the terms of sale; which certificates of stock shall be delivered to the vendor or vendors of such site ors ites, by the said commissioners, upon the conveyance to the Mayor and City Council of Baltimore of the property so purchased, and after the Counsellor of the city shall have certified to the sufficiency of the title or titles thereof; and should the said commission not be able to complete the purchase of said site or sites at one time, so as to be obliged to make several certificates to the Register, the same proceedings as those just mentioned shall be had in each and every case.

Sec. 2. And be it enacted and ordained, That the revenue derived and to be derived by the Mayor and City Council of Baltimore from the City Passenger Railways, be and the same is hereby pledged and set apart for the payment of the interest on the certificates of stock to be issued under this ordinance. 
SEC. 3. And be it enacted and ordained, That one-fifth of the revenue aforesaid, remaining after the payment of the interest aforesaid, shall be invested by the Register in the stock of the City of Baltimore, as a sinking fund for the redemption of the stock created by this ordinance.

SEc. 4. And be it enacted and ordained, That the fourfifths of said remaining revenue, shall be paid by the Register, on the order of the said commission, as the said revenue shall be received, for the improvement and maintenance of the Park or Parks aforesaid.

SEc. 5. And be it enacted and ordained, That said commission shall make annually to the Mayor and City Council of Baltimore, in season to be referred to in the annual message of the Mayor to the Council, a full and detailed report of their proceedings in the execution of the trust reposed in them, showing the character and quantity of work done and the moneys paid therefor, the persons in their employment, their duties and compensation, together with the plan proposed for their operations during the coming year.

SEc. 6. And be it enacted and ordained, That the present commission be, and they are hereby anthorized to take charge of the said Park or Parks, and the improvement and maintenance, including the preservation thereof, and to that end they are hereby clothed with all power necessary for that purpose, and may appoint and compensate such officer or officers, engineer or engineers, gardener or gardeners, and employ such lahorers as they may deem proper and necessary, and with power also to appoint and compensate guardians of the said property for the preservation of order within the limits thereof.

SEc. 7. And be it enacted and ordained, That the Mayor of the city, for the time being, shall always be a member of the commission ex officio.

SEc. 8. And be it enacted and ordained, That the said commission shall have power and anthority to dispose of, 
by sale or otherwise, any portion of said site or sites origri mally purchased, which may not be necessary for the purposes of said Park or Parks, as well as any crop, wood, trees, or other property that may be severable from the freehold, should it become necessary, in the improvement and maintenance of said Park or Parks so to do, in their judgment, and to make use of the avails thereof for the use of said Park or Parks. And the Mayor is hereby authorized to execute any conveyances, certified by the City Counsellor, that may be required therefor ; provided, however, that the joint expenses of sail improvement and mantenance shall not exceed in any year the net revenue that may be received under the provisions of this 8 th section, together with the said four-fifths of remaining revenue as set apart in the fourth section of this ordinance.

SEc. 9. And be it enacted and ordained, That the said commission shall have full power to make all agreements with proprietors in regard to division lines and enclosures, the arljusting thereof', and the exchanging of property for that purpose, and iu like manner the said commission shall have full power to agree for the closing of public roads, should any be found to run through said site or sites, or to make such arrangement thereof as shall enalule tnem to have entire control of the said l'ark or l'arks, the exclusion of improper parties, and the general police thereof?

SEC 10. And be it enacted and ordained, 'That in addition to the present commission, I'homas Swann, now a member thereof, as Mayor of the eity, ex officio, be and he is hereby appointed a commissioner in his individual capacity.

SEC. 11. And be it enacted and ordained, 'T'hat nothing herein contained shall be taken to authorize the payment of either salary or emoluments of any kind to the said commissioners, or any of them.

SEC. 12. And be it enacted and ordained, 'That should any vacancy occur in said commission from death, resig- 
nation or failure to serve, the same shall be filled by the said commission itself, and be by them reported to the Council for and subject to its approval, at the first session thereafter.

Approved July 21, 1860.

'I'ho: Swann, Mayor.

\section{CHAPTER 41.}

An Act to amend the Fourth Article of the Code of Public Local Laws by adding thereto the following sections, relating to the purchase and government of Druid Hill and Patterson Parks, belonging to the City of Baltimore.

Section 1. Be it enacted by the General Assembly of Maryland, That the Park Commission provided for under a resolution of the Mayor and City Council of Baltimore, approved June the fourth, eighteen hundred and sixty, and acting under an ordinance entitled, "An ordinance to provide for a Park or Parks, approved July twentyfirst, eighteen hundred and sixty, as well as under any future ordinance of the said Mayor and City Council," be and they are hereby authorized to make from time to time such rules and regulations for the government and the preservation of order within the said Parks, as they may deern expedient, declaring what fines, not exceeding, in any one case, one hundred dollars, shall be imposed for breaches of said rules and regulations, to be recoverable in the name of the said Mayor and City Council as small debts are recoverable before a Justice of the Peace of the City of Baltimore, and appropriated to the purposes of the said Parks.

SEc. 2. And be it enacted, That the members of the said Park Commission, for the time being, shall have the power respectively of conservators of the peace within the limits of said Parks. 
SEc. 3. And be it enacted, That the Board of Police of the said city are hereby authorized, on the requisition of the said Park Commission, to detail from time to time such of the regular police force as the said Board may deem necessary for the preservation of order within the said Parks, according to the regulations aforesaid, and under the direction of said Board of Police; which detailed force shall have the same power in the premises that the police of the said city have as conservators of the peace.

SEc. 4. And be it enacted, That the ordinance and resolution referred to in the first section of this act, be and the same are hereby ratified and confirmed, and that full porver be and the same is hereby given to the Mayor of the said city and the Register and the said Park Commission to carry into effect all the provisions of the said ordinance, in the same manner, to all intents and purposes, as if the said Mayor and City Council had been, previously to the passage of the said ordinance, authorized and empowered by an act of the General Assembly of Maryland to enact an ordinance in the precise terms of the ordinance above referrec to, and to provide for carrying the same into effect; provided, that nothing in this act shall be construed to affect any right whatsoever of the Green Spring Avenue Company.

Passed June 12, 1861.

This act has been repealed, but is inserted here, notwithstanding, for illustration, if need be. 


\section{CHAPTER 29.}

AN $\Lambda$ CT to ratify the purchase, and to provide for the organization and government of Druid Hill Park and Patterson Park, belonging to the City of Baltimore, by incorporating certain additional sections in Article four of the Code of Public Local Laws.

Section 1. Be it enacted by the General Assembly of Maryland, That the following be enacted and incorpo. rated as additional sections into Article Four of the Corle of Public Local Laws, under the title of Parks:

954. The resolution of the Mayor and City Council of Baltimore, "appointing a Commission in relation to the proposed Public Parks," approved June the fourth, eighteen hundred and sixty, and an ordinance of the said Mayor and City Council, "to provide for a Public Park or Parks," approved July the twenty-first, eighteen hundred and sixty, are hereby confirmed, and all acts done or which may be hereafter done by the said Mayor and City Council, or other officer of said city, or by the Park Commission acting under the provisions of said resolution and ordinance, shall have the same effect as if the said Mayor and City Council, prior to the passage of the said resolution and ordinance, had been expressly empowered by an act of the General Assembly of Iaryland, to enact a resolution and ordinance, in the precise terms of the said resolution and ordinance, and to provide for carrying the same into effect; but nothing herein is to affect any right whatsoever of the Green Spring Avenue Company.

955. The Park Commission, for the time being, appointed under the provisions of said resolution and ordinance, or any resolution or ordinance supplementary thereto, shall have power, from time to time, to make such rules and regulations for the government and the preservation of order within the said Parks as they may deem 
expeelient, leclaring what fines, not exceeling in any one case one hundred dollars, shall be imposed for breaches of said rules and regulations, to be recoverable in the name of the Mayor and City Conncil of Baltimore, as small debts are recoverable, before a Iustice of the P'ace of the said city, and appropriated to the purposes of said Parks.

956. 'T'he several nembers of the said Park Commission shall have the powers of a conservator of the peace within the limits of the said Parks.

957. The Board of Police of the said city are anthorized, on the requisition of the Park Commission, to detail, from time to time, such of the regular police force of said city, as the Board may deem necessury for the preservation of order within the said Parks, according to the regulations aforesaid, and under the direction of said Board; which detailed force shall have the same power in the premises, that the police of the city have as conservators of the peace.

958. If the said Park Commission shall find that they cannot arree with the owner of any land, or of any interest in land, which may be found necessary to be added to "Druid Hill Park," or if the owner thereof or any of the owners thereof, at the time of application be a feme covert, under age, non compos mentis, or residing out of Baltimore Cunnty, application may be made by the said Commissioners, to any Justice of the Peace of Baltimore County, who shall thereupon issue his warrant, under haud and seal, directed to the sheriff of the county, directing him to summon a jury of twenty inhabitants of said connty, not related to the parties, nor in any wise interested, to meet on the land to be valued on a day named in said warrant, not less than ten nor more than twenty days after issuing the same, and if at said time and place, any of siald jurors summoneel do not athend, the satid sheriff shall immediately summon as many jurous as way be 
necessary, with the jurors in attendance, to furnish a panel of twenty jurors in attendance, and from them each party or his ageut, or if either be not present, in person or by agent, the Sheriff for him, may strike off four jurors, and the remaining twelve shall act as the jury of iuquest; and before they act as such, the Sheriff shall administer to each of them an oath or affirmation, as the case may be, that he will justly ani impartially value the land required by said Mayor and City Council for the Park aforesaid; and the said jury shall reduce their inquisition to writing, and shall sign and seal the same, and it shall then be retu"ned by the said Sheriff to the Clerk of the Circuit Court for Baltimore County, to be filed in his Court, for confirmation by said Court at its next term, if no sufficient cause to the contrary be shown, and when returned, shall be recorded by the said Clerk at the expense of the said Mayor and City Council; but, if set aside, the Curnt may direct another inquisition to be taken in the manner above prescribed; and such inquisition shall describe the land taken, and the quantity or duration of the interest in the same, valieed for the Mayor and City Council, and such valuation, when paid or tendered to the owner of said land, or his or her legal representatives, shall entitle the said Mayor and City Council to the estate or interest so valued, as fully as if it had been conveyed by the owner thereof; and the valuation, if not received when tendered, may at any time thereafter be received from the said Mayor and City Council by the said owner.

959. The said Park Commissioners, are authorized to enlarge the streets and avenues around and leading to the said Park; and in the event of failing to agree with the owner of any property required for that purpose, or of any interest therein, for the purchase thereof', or if the owner be a feme covert, under age, non compos mentis, or be residing out of the County at the time, the said Commissioners are hereby authorized to condemn the same, in the manner 
specified in the foregroing section, the oath to each juror being, that he will justly and impartially value the ramacres which the owner will sustain by the enlarging of the particular street or avenue, as the case may be, and the jury, in estimating such damages, shall not make any allowance or deduction on account of any real or supposed benefits which the owner may derive from said Park, or from such enlargement of said street or avenue.

SEC. 2. And be it enacted, Thiat the Act "to amend the Fourth Article of the Code of Public Local Laws, by adding thereto the following sections, relating to the purchase and government of Druid Hill and Patterson Parks, belouging to the City of Baltimore, passed at April session, eighteen hundred and sixty-one, chapter forty-one, be and the sume is hereby repealed; the provisions thereof being incorporated in the preceding section.

SEc. 3. And be it enacted, That this Act shall take effect. from the passage thereof.

Passed January 31, 1862.

\section{CHAPTER 71.}

Extract from AN AcT entitled, An Act to incorporate the Baltimore City Passenger Railway Company.

SEction 4. And be it enacted, That the corporation hereby created be and they are hereby required to pay over to the Register of the (ity of Baltimore, the one-fith portion of the whole passenger receipts of this corporation, at or before the stated periods named in the aforesaid recited ordinance of the City of Baltimore; in default of which payments on or before the days appointed therefor, this corporation shall be liable to the penalty of one hundred dollars for each day of the continuance of such default after ten days after the expiration of each quarter, to be 
recovered by the said City of Baltimore according to law ; provided further, that the said corporation shall be subject to such police regulations, as the Mayor and City Council of Baltimore may hereafter, from time to time, enact by ordinance for the government of their conduct in the performance of their duties under this law, and provided also, that said corporation hereby created, shall provide books in which shall be entered by a Treasurer, under oath, the weekly receipts of sail Company, and that said books shall be open to the inspection of the Mayor and City Council of Baltimore.

Passed February 13, 1862.

No. 67.

An ORdinance authorizing the construction of a Pavilion in Druid Hill Park.

Be it enasted and ordained by the Mayor and City Council of Baltimore, That the Public Park Commissioners be and they are hereby authorized to borrow the sum of fifteen thousand dollars, or so much thereof as may be necessary for the purpose of enlarging and improving the Mansion House at Druid Hill Park, so as to convert the same into a central Pavilion for the accommodation of the public, to be secured by the rents of said Pavilion, and for that purpose the said commissioners are hereby empowered to assign the said rents in trust, and to appropriate so much as may be required to the payment of the interest on the borrowed sum, the balance to be set apart as a sinking fund for the extinguishment of the debt hereby authorized to be created; movided, that uo part of said interest shall be a charge on the city treasury, but 
shall be paid by the Park Commissioners from the funds provided for the support and mantenance of said Park.

Approved October 10, 1862.

John Lee Chapman, ex officio Mayor.

The above ordinance was never acted on, the subsequent appropriation by the city of $\$ 150,000$ fyrnishing the means for building the Pavilion.

\section{No. 37.}

An Ordinance to provide for improvements in Druid Hill Park and Patterson Park.

Wuereas, the Public Park Commission, in their third annual report, have designated various objects, which are desirable in view of affording the public the most advantagreous enjoyment of Druid Hill Park and Patterson Park, but which are beyond the present limited means of the Commission; and whereas, it is important that the improvement of said Parks be prosecuted with reasonable rapidity; therefore,

Section 1. Be it enacted and ordained by the Mayor and City Council of Baltimore, That whenever the Park Commission shall certify to the Register of the city, under their respective hands, that they require a sum of money for an object connected with the said Parks, said object to be at the same time designated, it shall be the duty of the Register to issue the bonds of the Mayor and City Council of Baltimore in the usual form, redeemable on the first day of January, 1895, bearing interest at the annual rate of six per centum, payable quarterly on the first day of January, A pril, July and October, and desigrnated as "Park Improvement Stock," for an amount suffi- 
cient to meet such requisition after retaining one-tenth of the par value for the purposes of a sinking fund, and the said Register shall sell the bonds so issued not under par, and out of the proceeds pay to the said Commission, the amount of their requisition or requisitions, from time to time, as the money may be needed: Provided, that the whole amount of bonds, so issued, shall not exceed the sum of one hundred and fifty thousand dollars for Druid Hill Park and twenty thousand dollars for Patterson Park, and should the Register sell the said bonds for more than par, the surplus sliall be retained by him, and applied to the payment of the first interest accruing upon said bonds.

SEC 2. And be it enacted and ordained, That after deducting from the revenue derived from the City Passenger Railways, the interest on the present issue of Park stock under the ordinance to provide for a public Park or Parks, and the sinking fund therein provided for, and the further sum of ten thousand dollars annually for the maintenance of the Parks, the surplus of said revenue, and the rent of the pavilion, and the net receipts from any passenger railway which may be laid within Druid Hill Park shall be applied, as far as necessary, to reimburse the city the interest upon the bonds hereby anthorized to be issued: Provided, that not more than one-eighth of the sum reserved in this section for the andual maintenance of the parks and of the excess of annual receipts from the City Passenger Railways over the amount necessary to provide for the interest on the bonds, issued under the provisions of this ordinance, shall be expended in the improvement and preservation of Patterson Park.

SEc. 3. And be it enacted and ordained, 'That one-tenth of the par value of said bonds retained by the Register, as directed in the first section, shall be invested by the Commissioners of Finance in the bonds of the City of Baltimore, or in bonds for which the city is liable by endorsement, as a sinking fund for the redemption of the bonds 
issued under the provisions of this ordinance, and that the proceeds of all sales or rents of any land south of Newington Lane, which may be sold or leased by the Park Commission, stall be paid to the Regrister of the city, to be invested by the Commissioners of Finance in the sinking fund herein provided tor, until the said fund shall, in the opinion of the said Commissioners, be adequate to the redemption of the bonds hereby anthorized, at their maturity, and the Register shall be the trustee thereof.

SEc. 4. And be it enacted and ordained, That should the Park Commission deem it expedient, they may, under the direction of the City Commissoner, lay down railway tracks on the North Avenue, between Madison lane and the Reisterstown road, with a view of facilitating the railway access to Druid Hill Park, subject to the same conditions as those establisher in the similar grant heretofore made to the President, Managers and Company of the Baltimore and Yorktown 'l'urnpike Roal, and the said Commission may delegate this power for a period not exceeding five years to any party with whom they may agree for the construction of a railway track or tracks to or within the Park: Provided, that the rate of fare shall not exceed three cents to each passenger for the trip, to or from the vicinity of the Pavilion, or five cents for the round trip, and that no fare shall be chargeable until the track is laid to a point within two hundred yards of the pavilion.

SEC. 5. And be it enacted and ordained, That with a view of increasing the storage of water for the supply of the city by the construction of lakes and reservoirs in Druid Hill Park and the land aljoining thereto, the Park Commission, under the direction of the Water Board, are authorized to lay a pipe from Hamplen Reservoir or from the conduit to a reservoir or reservoirs within the park, (to be constructed by the Park Commission,) and to keep the latter supplied with water from the former, under the 
control of the Water Board, having regard to the exigencies of the city, it being understood that the Park Commission will appropriate to the use of said Board for a still further storage of water, any land under the control of the Park Commission outsile of the limits of the Park, not affected by any existing agreements, and the Park Commission are hereby authorized to make sueh appropriation.

SEC. 6. And be it enacted and ordained, That for the purpose of supplying such portions of the city as cannot now be supplied from the present reservoirs, the Water Board shall have power, at their discretion, to use any of the reservoirs or lakes in Druid Hill Park, and to open the ground and lay down pipes in the said park, as they are now authorized to do within the limits of the city: Provided, that the Park Commission shall be consulted in the location of said pipes, and that the same shall be agreed upon by the two Commissions: Provided, however, that the Park Commissioners shall not make a requisition for, and the Register shall not be authorized to issue any of the bonds as provided for in section one of this ordinance, to pay any of the expenses of introducing water into Druid Hill Park from Hampden Reservoir, or otherwise, or for the construction of lakes and reservoirs for the reception of the same, except such as may be entirely supplied with water from springs in said park, until after the Pavilion has been so far completed as to be used by the public, and a permanent connection by a railway or otherwise, between the present terminus of the City Passenger Railway, at the corner of Northern Boundary and Madison Avenue and a point near the said pavilion has been made, and vehicles are regularly running in such way as to afford ample accommodations for passengers.

SEC. 7. And be it enacted and ordained, That ordinance No. 67, of the Ordinances for 1862, entitled "An Ordi- 
dance authorizing the construction of a Pavilion at Druid Hill Park," be and the same is hereby repealed.

Approved May 2, 1863.

John laee Chapman, Mayor.

\section{CHAPTER 141.}

Extract from AN Act to amend the Act to Incorporate the Green Spring Avenue Company, passed at the January session, one thousend eight huendred and fifty-eight, chapter two hundred and sixteen, and the Act amendatory thereof, passed at the January session, one thousand eight hundred and sixty, chapter one hundred and sixty-four, and to carry out the provisions of an agreement made betweon the said Company and the Mayor and City Council of Baltimore.

SEC. 2. And whereas, an agreement has been made between the said Company and the Mayor and City Council of Baltimore, whereby a road has been provided through Druid Hill Park, from the sonthern entrance thereof to an entrance already agreed upon on Woodbury lane, which roal is to be at all times hereafter kept open and in repair by the Park Commissioners, for use at all hours of the day and night, for such travel as is permitted by the general regulations of the Park, within its limits; therefore, be it enacted, that th- Green Spring Avenue Company are hereby released from the obligation of constructing their said avenue south of the northeru bundary of said Park.

SEC. 3. And be it enacted, That the said Druid Hill Park be and the same is hereby declared to he forever exempt from the passage through it, or the construction within it, of any public highway, turnpike or rail-road. 
Sec. 7. And be it enacted, That this Act shall be of non-effect until accepted by the Green Spring Avenue Company.

Passed March 2, 1864.

This Act was duly accepted by the Company.

\section{CHAPTER 170.}

A Suppiement to an Act entitled, An Act to incorporate the Baltimore City Passenger Railway Company.

Section 1. Be it enacted by the General Assembly of Maryland, That the Baltimore City Passenger Railway Company be, and they are hereby authorized and empowered to charge and collect six cents fare from each passenger passing from any one part of the City of Baltimore to any other part on the line of their railways without charge for transfer tickets, and one fitth of the gross receipts from passengers to be paid to the Register of the City of Baltimore, as provided for by the ordinance of the Mayor and City Council of said City.

Passed March 7, 1864. 


\section{CHAPTER 100.}

A Further Supplenent to an Act entitled, "An Act to incorporate the Baltimore City Passenger Railway Company."

Section 1. Be it enacted by the General Assembly of Maryland, That the Baltimore Passenger Railway Company be and they are hereby authorized and empowered to charge and collect six cents from each passenger pass ing from any part of the City of Baltimore to any other part, in any line of their railways, with a charge for transfer tickets of four cents; and one-fitth of the gross receipts from passengers to be paid to the Register of the City of Baltimore, as provided for by the ordinance of the Mayor and City Council of said City.

Passed March 16, 1865.

\section{No. 52.}

A Supplement to an ordinance entitled, "An ordinance to provide for Improvements in Druid Hill Park and Patterson Park."

Be it enacted and ordained by the Mayor and City Council of Baltimore, That in addition to the bonds authorized to be issued for Druid Hill Park by the ordinance to which this is a supplement, there shatl be issued in the manner provided in the said ordinance, the sum of twentyseven thousand dollars, to which additional sum all the provisions of said ordinance shall apply, as though the sum therein mentioned had included the sum now anthorized.

A pproved June 28, 1865.

Join Lee Chapman, Mayor. 
No. 60 .

An Ordinance relating to Druid Hill and Patterson Parks.

Section 1. Be it enacted and ordained by the Mlayor and City Council of Baltimore, That the Register of the city be and he is hereby authorized, in accounting with the Public Park Commission, to pay to them the revenue derived from the Passenger Railways without other deduction than the interest on the bonds issued for the purchase of said Parks, and the sinking fund as provided for in the several ordinances heretofore passed in relation to the Public Parks.

SEc. 2. And be it enacted and ordained, That the Register be and is hereby authorized to pay to the Public Park Commission, in such sums as may from time to time be required, fifty thousand dollars, of which sum ten thousand dollars shall be for the use exclusively of Patterson Park, and the remainder for Druid Hill Park.

Approved May 26, 1866.

John Lee Chapman, Mayor.

$$
\text { No. } 141 .
$$

,

Resolution to Provide Concerts at the Parks.

Whereas, the instrumental concerts provided by the city at Druid Hill and Patterson Parks last year added much to the attractions of these popular places of resort, being duly appreciated by, and giving much gratification to, the large number of our citizens who attended them, it is deemed advisable that they should be continued this year, therefore 
Resolved by the Mayor and City Council of Baltimore, That the Mayor be and he is hereby authorized to contract with a suitable person to superintend the giving of instrumental concerts in Druid Hill and Patterson Parks, on such days, during the summer and fall months, as he may deem proper, and that the sum of twelve hundred dullars, or so much thereof as may be necessary, be and the same is hereby appropriated to pay the expenses thereof, to be taken out of the levy of 1866 .

Approved May 21, 1866.

John Lee Chapman, Mayor 


\title{
RULES AND REGULATIONS
}

\author{
FOR THE GOVERNMENT OF
}

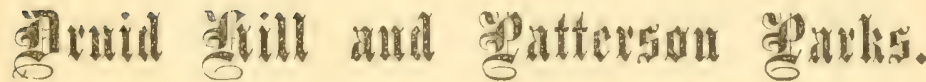

1. If any person shall discharge any Fire-Arm within the Park, such person shall forfeit and pay Five Dollars for every offence.

2. Dogs are prohibited; and, if any person, having a Dog within the Park, refuses, when requested, to take him out, such person shall forfeit and pay Five Dollars.

3. If any person shall Drive or Ride upon the Grass, or Footways, or elsewhere than on the Roads for the use of Carriages and Equestrians such person shall forfeit and pay Five Dollars for every offence-the owner of the Carriage, in the case of Driving to be responsible.

4. If any person shall Drive or Ride faster than at tue rate of Six Miles an Hour, such person sifall furfeit and pay Five Dollars for the first offence, and Twenty Dollars for eVeriy succeeding offence.

5. If any person shall pull any Flowers or Fruit, whether wild or cultivated-cut down Trees or Sap'ingsbreak limbs, or Branches of Trees, or Bark 'I'rees-or injure Shrubbery, or plauts, such person shall forfeit and pay not less than Five Dollars, nor more than One Hundred Dollars, for every offence. 
6. If any person shall Girdle any Tree, such person shall forfeit and pay not less than Twenty, nor more than One Hundred Dollars.

7. If any person shall commit a nuisance, or any offence against decency or good morals, such person shall forfeit and pay not less than Five, nor more than Fifty Dollars, for every offence.

8. If any person shall Write upon any building, Bench, Statuary, Ornament, or other Property, or in any manner cut, deface, or mutilate the same, such person shall forfeit and pay Five Dollars for every offence.

9. If any person shall throw Stonęs, or Rubbish of any kind, into any Lake or Pond of the Park, such person shall forfeit and pay Five Dollars for every offence.

10. If any person shall Bathe in any Lake or Pond of the Park, such person shall forfeit and pay Five Dollars for every offence.

11. If any person shall Chase, set Snares for, or Catch, any Rabbits, Squirrels, Birds or Fish, within the Park, such person shall forfeit and pay Five Dollars for every offence.

12. If any person shall Curse or Swear, or use abusive language, or Fight, or Throw Stones, or behave in a Riotous or Disorderly Manner, such person shall forfeit and pay Five Dollars for every offence.

13. If' any person shall introrluce any Spirituous Liquors into the Park, either for his own use or for sale, and shall use, or sell, or give the same, such person shall pay not less than Five, nor more than Twenty Dollars.

14. If any person shall set up any Booth, or Table, for the sale of any article whatever, without the consent of the Park Commission, such person shall forfeit and pay Five Dollars for every offence; and the Both or Table shall be removed.

15. If any persou shall attach a Swing to any tree within the Park, withont the consent of the Superinten- 
dent, or person in charge of the Park, such person shall forfeit and pay Five Dollars for every offence.

16. If any person shall Climb a Tree, such person shall forfeit and pay Five Dollars for every offence.

17. If any person shall Foul in any manner any Spring or Branch, such person shall forfeit and pay not less than Five, nor more than Ten Dollars.

18. When Carriages or Equestrians meet, the parties respectively, shall keep to the right, as the law of the Road.

19. If any person shall break, or in any manner injure the Enclosure of the Park, such person shall forfeit and pay the sum of Five Dollars for every offence, in addition

- to the cost of repairing the injury.

20. The Gates shall be opened at Sunrise, and closed at Dark. After the Gates are closed, they will be opened only to permit egress, but not ingrẹss of visitors to the Park.

21. If any person shall fasten a Horse to a 'T'ree, such person shall forfeit and pay Five Dollars for every offence.

22. Any person found Intoxicated in the Park, may be removed therefrom by the Police, and the Gate Keepers are authorized to prevent the ingress of any such person.

23. Gambling, and Playing Cards, is prohibited, under a penalty of Five Dollars, to be forfeited and paid by each of the parties to the game.

24. If any person shall make a Fire, for any purpose on the grounds of the Park, such person shall forfeit and pay Five Dollars for every offence.

25. If any person shall trespass on Ground Enclosed with a rail, such person shall be subject to a fine of Five Dollars.

26. The Pic-nics permitted in the Park are those of Sunday and other Schools, when accompanied by their respective Teachers and Masters, who will be held personally responsible for all infringements by the Scholars of 
these Rules and Regulations, in the penaltics severally prescribed herein.

27. No Pic-nic shall take place in the Park without a written permission for the purpose being first obtained from the Superintendent, or person in charge of the Park, in which shall be designated the spot where it shall be held. If' any person shall attempt to hold a Pic-nic withont snch permission, each person engaged therein shall forfeit and pay Five Dollars, besides being liable to be turned ont of the Park.

28. Parties holding Pic-nics in the Park are expected to clean up the grouml that has been occupied by them, on quitting it, and not to leave paper to be blown about on the premises.

29. If any person shall disturb any Pic-nic, or intrude him or herself' apon it without the consent of those composing it, such person shall forleit and pay Five Dullars for every offence.

30. 'The experience of the Commission renders the enforcement of the above Regulations in regard to Pic-nics indispensable to the preservation of the property, and the comfort and protection of the visitors.

\section{PARK COMIMISSION.}

July 2d, 1861. 





\section{LIBRARY OF CONGRESS}

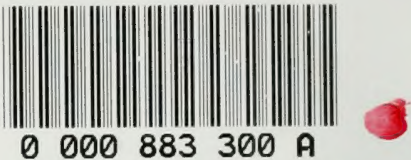

